\title{
Breeding biology and nidology of Oriental skylark (Alauda gulgula) in district Bajaur, Khyber Pakhtunkhwa, Pakistan
}

\author{
Karim Gabol ${ }^{1 *}$ and Rahmat Ullah Khan ${ }^{1}$ \\ 1. Department of Zoology, University of Karachi, Karachi-75270-Pakistan \\ *Corresponding author’s email: kgabol.gabol@gmail.com/rahmatullahkhanpk@gmail.com \\ Citation \\ Karim Gabol and Rahmat Ullah Khan. Breeding biology and nidology of Oriental skylark (Alauda gulgula) in \\ district Bajaur, Khyber Pakhtunkhwa, Pakistan. Pure and Applied Biology. Vol. 10, Issue 4, pp1326-1337. \\ http://dx.doi.org/10.19045/bspab.2021.100137
}

\begin{tabular}{|c|c|c|c|}
\hline Received: $21 / 12 / 2020$ & Revised: 19/02/2021 & Accepted: 23/02/2021 & Online First: $13 / 03 / 2021$ \\
\hline
\end{tabular}

\section{Abstract}

A general field survey about Oriental skylark (Alauda gulgula) breeding biology and nest structure (nidology) was carried out during (April, May, June, and July) 2018 and 2019, in district Bajaur. This study was conducted in order to record all the ecological factors that hurdle for the successful breeding of skylark in the study area. For this purpose, we studied 33 nests from egg laying up to the fledging stage. As a result, morphometric measurements of 112 eggs were recorded. Overall eggs were oval dusty white or grey white with black spots and mostly smooth or of somewhat rough texture. Average egg weight $3.0 \mathrm{~g}$, length $2.2 \mathrm{~cm}$, width $3.27 \mathrm{~cm}^{2}$ and volume $3.65 \mathrm{~cm}^{3}$. Likewise explored average clutch size 3.39, incubation period 12.07 days, the number of eggs hatched 3.30 (95.19\%), fledged 3.18 (97.34\%), and breeding success (89.20\%). After normal fledging, the floor of nests was recorded. The shape of nests was entirely round to preferential round; the average nest diameter $9.48 \pm 0.8 \mathrm{~cm}$, cup diameter $7.86 \pm 0.6 \mathrm{~cm}$, cup depth $6.21 \pm 0.5 \mathrm{~cm}$, and nest weight $17.61 \pm 0.9 \mathrm{~g}$. The main cause of breeding failure and nest loss was brutal nests and egg destruction by locals and a high rate of land as well avian predators.

Keywords: Bajaur; Breeding biology; Clutch size; Nidology; Oriental skylark

\section{Introduction}

Oriental skylark (Alauda gulgula) was primarily investigated in Laos during 1997 [1]. It is a small sized bird [2], having a wide dispersal range around Asia including Northern Pakistan, Europe, and Africa. They build their nests on the ground [3,4]. It is the only passerine bird that shows a great association with agricultural farmlands $[5,6]$. Skylark has eleven to thirteen subspecies [7, 8]. They mostly select dry habitats with moderate grasses and agricultural crop-lands for nest construction. Oriental skylark constructs a cup-shaped nest in a shallow depth in the soil from threads and soft grass for breeding purposes $[9,10]$. Nest construction and incubation are completed by females, but both parents feed the nestlings. The clutch is 2 to 5 eggs, eggs hatch after 12 days. Chicks start flying at the age of 8 to 11 days. They become independent of their parents at the age of 30 days. A single couple makes two to four nesting attempts in a year. The first clutch was laid in early April, and 
the last broods were fed in late July. The territorial range differs mostly, but the average territories cover an area of 5000$20,000 \mathrm{~m}^{2}$. Bird pairs change their territories when there is a change in vegetation and environmental conditions [11, 12]. In Western Europe, Oriental skylark population density dropped over the last 30 years due to rapid amplification in farming land [5]. Oriental skylarks were therefore considered a priority species associated with agriculture and cultivated lands for conservation and rehabilitation [12 ]. Among the passerines, more than $70 \%$ of nest destruction and failure was that of Oriental skylark. However, nest achievement in different crops was different [12-15].

The highest population density of Oriental skylark was observed in habitats where crops were more diverse; as crop types offer more suitable habitats for nest construction throughout the breeding period [15]. Oriental skylark does not inhabit vegetation more than 30 to $35 \mathrm{~cm}$ in height $[15,16]$.

Little data are available on the ecology of Oriental skylark in Pakistan. The population of Oriental skylark is low in Bajaur due to the loss of habitat and low productivity. So a comprehensive study was conducted about skylark nidology and breeding biology in district Bajaur, Khyber Pakhtunkhwa, Pakistan from April-July 2018 and April-July 2019 respectively.

\section{Materials and Methods}

\section{Study area}

The study was conducted on the farmland and rainfed croplands in district Bajaur $\left(34^{0} 44.161 \mathrm{~N}, 71^{0} 31.631 \mathrm{E}\right), 850-1100 \mathrm{~m}$ elevation above mean sea level, covering an area of $1290 \mathrm{~km}^{2}$ [17-19] (Fig. 1).

\section{Field survey}

The data were collected on the breeding biology and nidology of Oriental skylark in the study area. Potential sites were surveyed from March to July 2018 and 2019. Oriental skylarks and their nests were searched in the study area using binoculars $(7 \times 50 \mathrm{~mm})$ and numbered serially for data collection (Fig. 1). GPS coordinates of each nest were recorded (Table 1). Data on breeding season, egg shape, color, texture, etc. were recorded three times a week in the morning and in the evening (Tables $2 \& 3$, Fig. 2b, 2c, 2d, 2e, 2f). A digital camera was used to photograph the nests, eggs and nestlings. Data were recorded causing minimum disturbance to the habitat, birds, and nest predation following. Vernier caliper was used to measure eggs. A digital scale of $0.1 \mathrm{~g}$ to $1000 \mathrm{~g}$ was used to weigh eggs, and nests. The volume of eggs was determined by using the following formula No 1:

Volume $=\mathrm{Kv} X L W 2$

Where " $\mathrm{KV}$ " is constant $=0.51$, " $\mathrm{L}$ " and " $\mathrm{W}_{2}$ " are the length and width of skylark eggs respectively.

The breeding patterns associated with oriental skylark were determined during the breeding seasons, these patterns were clutch size, incubation period, hatching success, fledging success, and breeding success. The hatching success, fledging success, and overall breeding success were calculated according to Kour [20], by the following formulas;

$$
\begin{aligned}
\text { Hatching success } \% & =\frac{\text { Number of egg hatched }}{\text { Total egg laid }} X 100 \\
\text { Fledging success } \% & =\frac{\text { Number of fledging }}{\text { Number of egg hatched }} X 100 \\
\text { Breeding success } \% & =\frac{\text { Number of fledging }}{\text { Total number of egg laid }} \times 100
\end{aligned}
$$




\section{Statistical analysis}

Sample sizes varied for different parameters about breeding biology and nest characterization because we couldn't compare breeding variables for statistical significance due to the low sample size. However, analyzed as mean \pm standard deviation for both comparison and standard errors by MS Excel (365).

\section{Results}

Oriental skylark breeding biology and nidology were explored during the breeding season from April to July 2018 and 2019. Thirty-three nests were investigated. Some nests were explored while being constructed ( $9^{\text {th }}$ and $16^{\text {th }}$ April). The initiation of the breeding period of one skylark pair was recorded on $25^{\text {th }}$ April, that which lasted up to mid-May, 2018. The remaining breeding pairs were recorded during mid-April, May and June 2018 and 2019 (Table 3 \& 4).

The clutch size ranged from 2 to 4 eggs (3.39 \pm 0.9$)$. The dimensions of eggs varied. All eggs were oval-shaped, the average weight of eggs was $3.00 \pm 0.1 \mathrm{~g}$. Similarly, the average eggs length $2.20 \pm 0.04 \mathrm{~cm}$, the average width of the eggs $3.27 \pm 0.16 \mathrm{~cm}^{2}$ and the average volume $3.65 \pm 0.07 \mathrm{~cm}^{3}$, color grey white with black spots and smooth surface (Table $2 \&$ Fig. 2b, 2c, 2d); the incubation period 11 to $13(12.07 \pm 0.4)$ days. Hatching success was $95.19 \%$ probably due to the high predation rate. Nestlings fledged after 9 to 14 days of hatching and left the nests. A fully grown nestling on the $14^{\text {th }}$ day weighed about $27.5 \mathrm{~g}$ (Fig. 2f). The fledging rate was $97.34 \%$ of the hatched eggs and the overall breeding success was $89.20 \%$ (Table 3).

During the nest construction activity, both males and females equally participated in nest construction. Most activities was observed during the early morning by about 8:00 am. In the presence of any observer, the birds remained flying 50 to $100 \mathrm{~m}$ from the nest while singing melodious songs (Fig. 2a). A total of 112 eggs, were noted in all 33 nests. Out of 112 eggs 86 were hatched successfully while 26 eggs were destroyed due to mammalian predation and anthropogenic ignorance as shown in (Table 3).

Dimensions of each nest were recorded. All the nests were constructed on the ground in natural vegetation and in wheat and barley fields. Outline of the $81.81 \%$ nests was completely round while remaining the $18.19 \%$ were partially oblong to round. The average external diameter of all the nests was $9.48 \pm 0.8 \mathrm{~cm}$, internal (Cup) diameter $7.86 \pm 0.6 \mathrm{~cm}$, average cup depth $6.38 \pm 0.5 \mathrm{~cm}$, and the average weight of the nesting material $17.61 \pm 0.9 \mathrm{~g}$. Nesting material used to construct all the nests mainly consisted of local grasses and dry leaves of trees and local crops including Dichanthiu annulatum (18\%). Desmostachya bipinnata (15\%), Heteropogon contortus (15\%), Cynodon dactylon (18\%), Fimbristylis squarrosa, (10\%) Phragmites communis (5\%), local crops dry leaves (14\%), plastic string (2\%), contour feathers (2\%) and $1 \%$ undifferentiated materials as shown in (Table 4). 


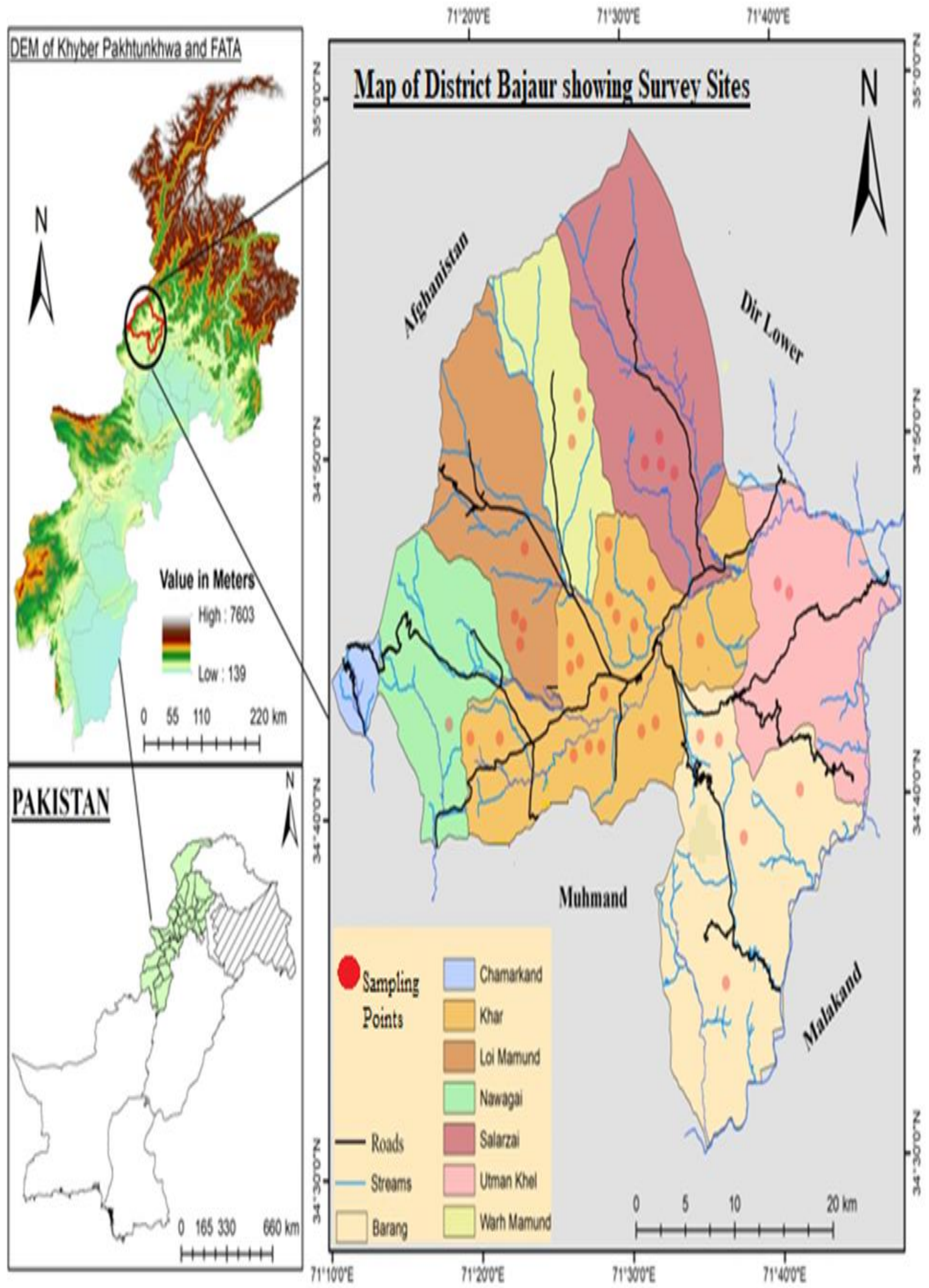

Figure 1. Map of District Bajaur small dots representing sampling points 


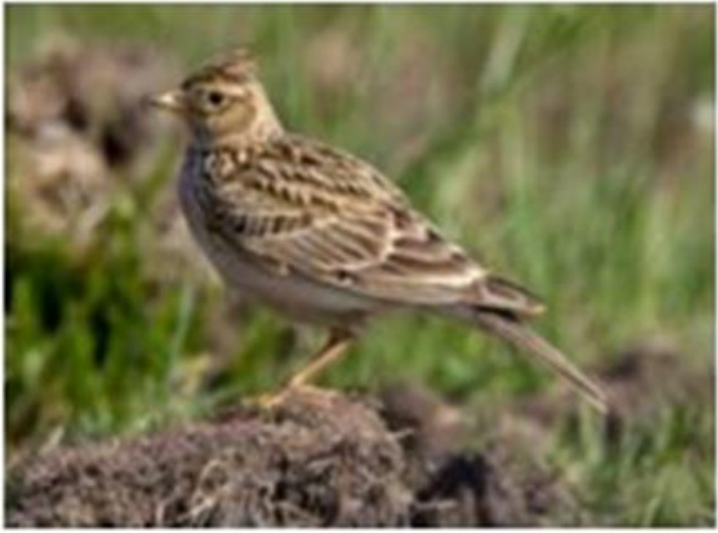

a)

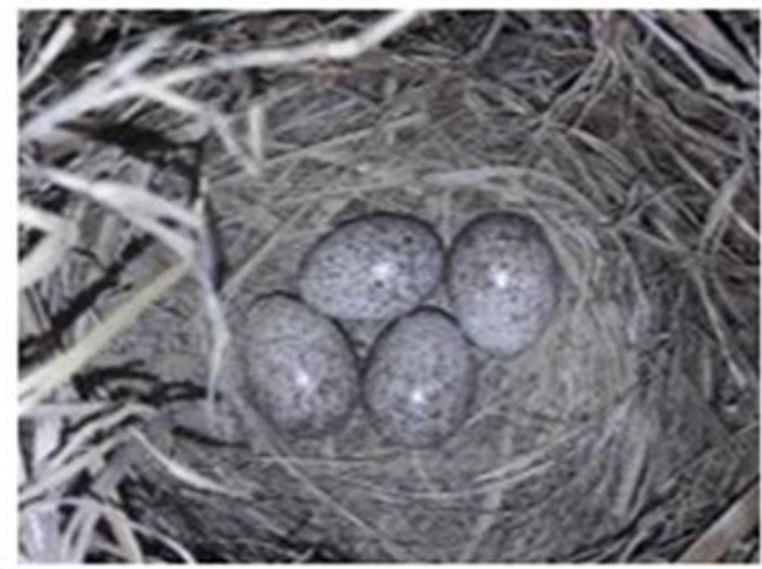

c)

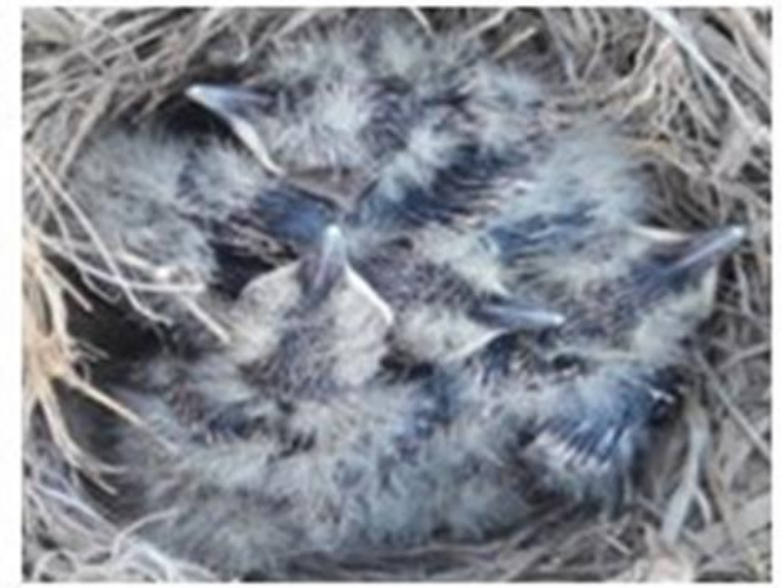

e)

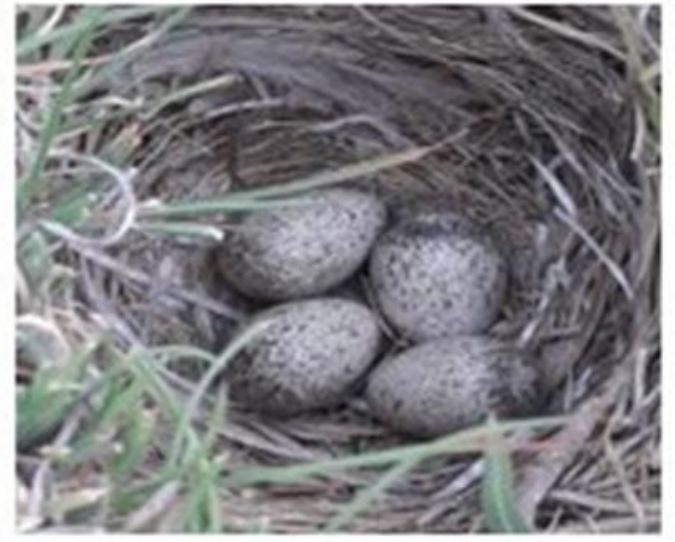

b)

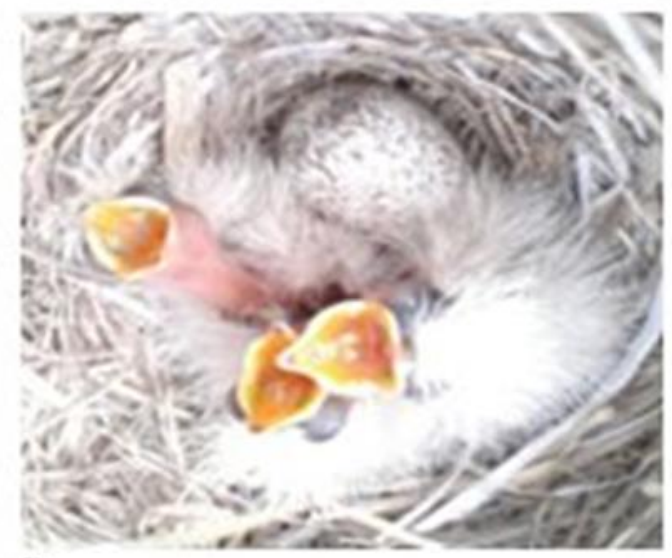

d)

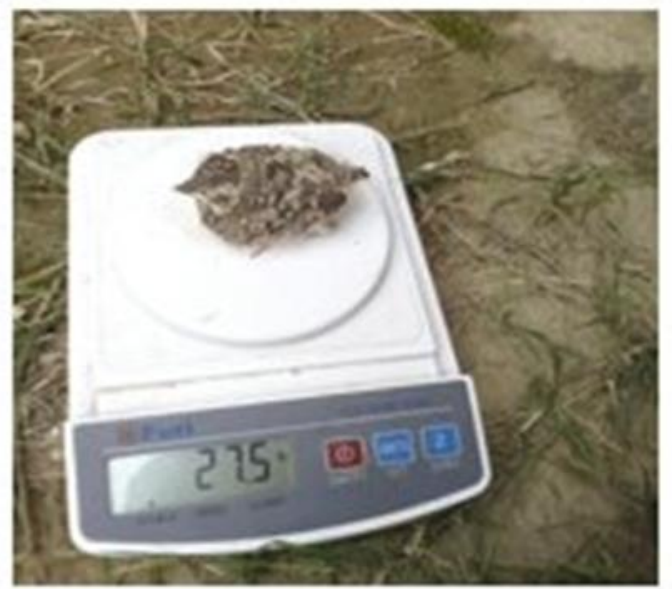

f)

Figure 2a. A sketch of an adult Skylark b) A photo of Skylark nest with 4 oval shape white eggs with black spots c) A sketch of completely round nest consist of four eggs d) First day hatched broods e) Nestlings with developing wings and feather f) A developed Nestling of about $27.5 \mathrm{gm}$ ready to left the nest 
Table 1. GPS locations of all 33 nests of Skylark in district Bajaur

\begin{tabular}{|c|c|c|c|c|c|}
\hline N. No. & Area Name & $\mathbf{N}$ & $\mathbf{E}$ & Elevation & Nesting habitat \\
\hline 1 & Rasaky & $34^{\circ} 42.611$ & $071^{\circ} 24.854$ & $940 \mathrm{~m}$ & Farmland \\
\hline 2 & ShehKaly & $34^{\circ} 42.675$ & $71^{\circ} 25.552$ & $874 \mathrm{~m}$ & Rainfed croplands \\
\hline 3 & Dehly & $34^{\circ} 42.730$ & $071^{\circ} 25.762$ & $890 \mathrm{~m}$ & Farmland \\
\hline 4 & Kawser & $34^{\circ} 42.821$ & $071^{\circ} 25.762$ & $914 \mathrm{~m}$ & Farmland \\
\hline 5 & Khazana & $34^{\circ} 42.921$ & $071^{\circ} 27.346$ & $908 \mathrm{~m}$ & Farmland \\
\hline 6 & Shagy & $34^{\circ} 43.977$ & $071^{\circ} 24.303$ & $972 \mathrm{~m}$ & Farmland \\
\hline 7 & Patak & $34^{\circ} 43.660$ & $071^{\circ} 28.947$ & $900 \mathrm{~m}$ & Farmland \\
\hline 8 & Shande & $34^{\circ} 43.485$ & $071^{\circ} 29.895$ & $868 \mathrm{~m}$ & Rainfed croplands \\
\hline 9 & Tankhat & $34^{\circ} 43.369$ & $071^{\circ} 27.609$ & $899 \mathrm{~m}$ & Rainfed croplands \\
\hline 10 & Khar West & $34^{\circ} 43.689$ & $071^{\circ} 30.193$ & $883 \mathrm{~m}$ & Farmland \\
\hline 11 & Khar South & $34^{\circ} 43.016$ & $071^{\circ} 31.262$ & $861 \mathrm{~m}$ & Rainfed croplands \\
\hline 12 & Khar East & $34^{\circ} 44.126$ & $071^{\circ} 31.618$ & $870 \mathrm{~m}$ & Farmland \\
\hline 13 & Yousaf Abad & $34^{\circ} 45.214$ & $071^{\circ} 32.651$ & $821 \mathrm{~m}$ & Rainfed croplands \\
\hline 14 & BokyGhado & $34^{\circ} 39.545$ & $071^{\circ} 21.323$ & $1070 \mathrm{~m}$ & Rainfed croplands \\
\hline 15 & Shah Nary & $34^{\circ} 46.091$ & $071^{\circ} 34.289$ & $821 \mathrm{~m}$ & Farmland \\
\hline 16 & Loisum & $34^{\circ} 41.887$ & $071^{\circ} 23.797$ & $962 \mathrm{~m}$ & Farmland \\
\hline 17 & Sabagy & $34^{\circ} 41.656$ & $071^{\circ} 23.104$ & $961 \mathrm{~m}$ & Rainfed croplands \\
\hline 18 & Maskanu & $34^{\circ} 41.436$ & $071^{\circ} 21.493$ & $1008 \mathrm{~m}$ & Rainfed croplands \\
\hline 19 & Zoor Bander & $34^{\circ} 41.265$ & $071^{\circ} 20.406$ & $1100 \mathrm{~m}$ & Rainfed croplands \\
\hline 20 & Ghandow & $34^{\circ} 41.182$ & $071^{\circ} 20830$ & $1031 \mathrm{~m}$ & Farmland \\
\hline 21 & TangiDery & $34^{\circ} 43.376$ & $071^{\circ} 21.535$ & $1019 \mathrm{~m}$ & Farmland \\
\hline 22 & Loijoher & $34^{\circ} 42.653$ & $071^{\circ} 22.606$ & $989 \mathrm{~m}$ & Farmland \\
\hline 23 & Samsy & $34^{\circ} 41.106$ & $071^{\circ} 25.502$ & $961 \mathrm{~m}$ & Rainfed croplands \\
\hline 24 & Dozakh Shah & $34^{\circ} 42.845$ & $071^{\circ} 24.850$ & $940 \mathrm{~m}$ & Rainfed croplands \\
\hline 25 & Inayat Kaly & $34^{\circ} 45.244$ & $071^{\circ} 27.198$ & $851 \mathrm{~m}$ & Farmland \\
\hline 26 & Ber Kaly & $34^{\circ} 46.623$ & $071^{\circ} 25.359$ & $974 \mathrm{~m}$ & Farmland \\
\hline 27 & Umary & $34^{\circ} 45.244$ & $071^{\circ} 27.198$ & $851 \mathrm{~m}$ & Farmland \\
\hline 28 & Kamer sir & $34^{\circ} 46.623$ & $071^{\circ} 25.359$ & $974 \mathrm{~m}$ & Rainfed croplands \\
\hline 29 & Samsy khor & $34^{\circ} 41.106$ & $071^{\circ} 25.502$ & $961 \mathrm{~m}$ & Rainfed croplands \\
\hline 30 & Umer shah & $34^{\circ} 41.847$ & $071^{\circ} 25.055$ & $1100 \mathrm{~m}$ & Farmland \\
\hline 31 & Redawen Shah & $34^{\circ} 43.974$ & $071^{\circ} 23.636$ & $975 \mathrm{~m}$ & Rainfed croplands \\
\hline 32 & Janat Shah dog & $34^{\circ} 43.808$ & $071^{\circ} 23.611$ & $882 \mathrm{~m}$ & Farmland \\
\hline 33 & Serkanu Shah & $34^{\circ} 43.774$ & $071^{\circ} 23.956$ & $962 \mathrm{~m}$ & Rainfed croplands \\
\hline \multicolumn{6}{|c|}{ “N. No" (Nest number), "N" (North), “E” (East). } \\
\hline
\end{tabular}


Table 2. Oriental skylark eggs morphometric dimensions in Bajaur, during April to July 2018 and 2019 respectively

\begin{tabular}{|c|c|c|c|c|c|c|c|}
\hline $\begin{array}{l}\text { N. } \\
\text { No. }\end{array}$ & $\begin{array}{c}\text { E. } \\
\text { look }\end{array}$ & Egg color & Texture & $\begin{array}{c}\text { E. mass } \\
(\mathrm{g})\end{array}$ & $\begin{array}{l}\text { E. W. } \\
\left(\mathrm{cm}^{2}\right)\end{array}$ & $\begin{array}{l}\text { E. L. } \\
\text { (cm) }\end{array}$ & $\begin{array}{l}\text { E. V. } \\
\left(\mathrm{cm}^{3}\right)\end{array}$ \\
\hline 1 & Oval & Dusty white with BS & Smooth & 2.9 & 3.24 & 2.2 & 3.63 \\
\hline 2 & Oval & Grey white with BS & Smooth & 3.2 & 3.61 & 2.3 & 3.80 \\
\hline 3 & Oval & Grey white with BS & Smooth & 3 & 3.24 & 2.2 & 3.63 \\
\hline 4 & Oval & Grey white with BS & Smooth & 3 & 3.24 & 2.2 & 3.63 \\
\hline 5 & Oval & Grey white with BS & Smooth & 3 & 3.24 & 2.2 & 3.63 \\
\hline 6 & Oval & Grey white with BS & Smooth & 2.8 & 2.89 & 2.1 & 3.47 \\
\hline 7 & Oval & Dusty white with BS & $\begin{array}{l}\text { Small } \\
\text { rough }\end{array}$ & 2.9 & 3.24 & 2.2 & 3.63 \\
\hline 8 & Oval & Grey white with BS & Smooth & 3 & 3.24 & 2.3 & 3.80 \\
\hline 9 & Oval & Grey white with BS & $\begin{array}{l}\text { Small } \\
\text { rough }\end{array}$ & 3 & 3.24 & 2.2 & 3.63 \\
\hline 10 & Oval & Grey white with BS & Smooth & 3 & 3.24 & 2.2 & 3.63 \\
\hline 11 & Oval & Dusty white with BS & Smooth & 3.1 & 3.24 & 2.2 & 3.63 \\
\hline 12 & Oval & Grey white with BS & Smooth & 3.2 & 3.24 & 2.3 & 3.63 \\
\hline 13 & Oval & Grey white with BS & Smooth & 3.3 & 3.61 & 2.3 & 3.63 \\
\hline 14 & Oval & Grey white with BS & Smooth & 3 & 3.24 & 2.2 & 3.63 \\
\hline 15 & Oval & Grey white with BS & Smooth & 3.1 & 3.24 & 2.2 & 3.63 \\
\hline 16 & Oval & Grey white with BS & Smooth & 3 & 3.24 & 2.1 & 3.63 \\
\hline 17 & Oval & Dusty white with BS & $\begin{array}{l}\text { Small } \\
\text { rough }\end{array}$ & 2.9 & 3.24 & 2.2 & 3.63 \\
\hline 18 & Oval & Grey white with BS & Smooth & 2.8 & 3.24 & 2.3 & 3.63 \\
\hline 19 & Oval & Grey white with BS & $\begin{array}{l}\text { Small } \\
\text { rough }\end{array}$ & 2.8 & 3.24 & 2.2 & 3.63 \\
\hline 20 & Oval & Grey white with BS & Smooth & 2.9 & 3.24 & 2.2 & 3.63 \\
\hline 21 & Oval & Dusty white with BS & Smooth & 3.2 & 3.61 & 2.3 & 3.80 \\
\hline 22 & Oval & Grey white with BS & Smooth & 3 & 3.24 & 2.2 & 3.63 \\
\hline 23 & Oval & Grey white with BS & Smooth & 3 & 3.24 & 2.2 & 3.63 \\
\hline 24 & Oval & Grey white with BS & Smooth & 3 & 3.24 & 2.2 & 3.63 \\
\hline 25 & Oval & Grey white with BS & Smooth & 2.8 & 2.89 & 2.2 & 3.47 \\
\hline 26 & Oval & Grey white with BS & Smooth & 2.9 & 3.24 & 2.1 & 3.63 \\
\hline 27 & Oval & Dusty white with BS & $\begin{array}{l}\text { Small } \\
\text { rough }\end{array}$ & 3 & 3.24 & 2.2 & 3.63 \\
\hline 28 & Oval & Grey white with BS & Smooth & 3 & 3.24 & 2.3 & 3.63 \\
\hline 29 & Oval & Grey white with BS & $\begin{array}{l}\text { Small } \\
\text { rough }\end{array}$ & 3 & 3.24 & 2.2 & 3.63 \\
\hline 30 & Oval & Grey white with BS & Smooth & 3.1 & 3.24 & 2.2 & 3.63 \\
\hline 31 & Oval & Dusty white with BS & Smooth & 3.2 & 3.61 & 2.3 & 3.80 \\
\hline 32 & Oval & Grey white with BS & $\begin{array}{l}\text { Small } \\
\text { rough }\end{array}$ & 3.2 & 3.61 & 2.3 & 3.80 \\
\hline 33 & Oval & Grey white with BS & Smooth & 3 & 3.24 & 2.2 & 3.63 \\
\hline \multicolumn{4}{|c|}{ Mean \pm standard deviation } & $3.0 \pm 0.12$ & $3.27 \pm 0.16$ & $2.20 \pm 0.4$ & $3.65 \pm 0.07$ \\
\hline
\end{tabular}

"B.S” (Black Spots), “N. No" (Nest number), "E.W” (Egg width), "E.L” (Egg Length), "E.V” (Egg volume). 
Table 3. Breeding pattern of Oriental skylark in Bajaur, from March to July 2018 and 2019 respectively

\begin{tabular}{|c|c|c|c|c|c|c|c|}
\hline N. No. & $\begin{array}{l}\text { Clutch } \\
\text { size }\end{array}$ & $\begin{array}{c}\text { Incubation } \\
\text { period }\end{array}$ & $\begin{array}{c}\text { Eggs } \\
\text { hatched }\end{array}$ & HS (\%) & $\begin{array}{c}\text { No of } \\
\text { young } \\
\text { fledged }\end{array}$ & FS (\%) & $\begin{array}{c}\text { Breeding } \\
\text { success } \\
(\%) \\
\end{array}$ \\
\hline 1 & 2 & 12 & 2 & $100 \%$ & 2 & $100 \%$ & 100 \\
\hline 2 & 2 & - & - & - & - & - & - \\
\hline 3 & 2 & 11 & 2 & $100 \%$ & 2 & $100 \%$ & 100 \\
\hline 4 & 2 & 12 & 1 & $50 \%$ & 1 & $50 \%$ & 25 \\
\hline 5 & 2 & 12 & 2 & $100 \%$ & 2 & $100 \%$ & 100 \\
\hline 6 & 2 & - & - & - & - & - & - \\
\hline 7 & 2 & 11 & 2 & $100 \%$ & - & - & - \\
\hline 8 & 2 & 12 & 2 & $100 \%$ & 2 & $100 \%$ & 100 \\
\hline 9 & 2 & - & - & - & - & - & - \\
\hline 10 & 2 & 12 & 2 & $100 \%$ & 2 & $100 \%$ & 100 \\
\hline 11 & 4 & 12 & 4 & $100 \%$ & 4 & $100 \%$ & 100 \\
\hline 12 & 4 & 13 & 4 & $100 \%$ & - & - & - \\
\hline 13 & 4 & 12 & 4 & $100 \%$ & 4 & $100 \%$ & 100 \\
\hline 14 & 4 & - & - & - & - & - & - \\
\hline 15 & 4 & 12 & 4 & $100 \%$ & 4 & $100 \%$ & 100 \\
\hline 16 & 4 & 12 & 4 & $100 \%$ & 4 & $100 \%$ & 100 \\
\hline 17 & 4 & 13 & 4 & $100 \%$ & 4 & $100 \%$ & 100 \\
\hline 18 & 4 & - & - & - & - & - & - \\
\hline 19 & 4 & 12 & 4 & $100 \%$ & 4 & $100 \%$ & 100 \\
\hline 20 & 4 & 12 & 4 & $100 \%$ & 4 & $100 \%$ & 100 \\
\hline 21 & 4 & 12 & 4 & $100 \%$ & - & - & - \\
\hline 22 & 4 & 12 & 4 & $100 \%$ & 4 & $100 \%$ & 100 \\
\hline 23 & 4 & - & - & - & - & - & - \\
\hline 24 & 4 & 12 & 4 & $100 \%$ & 4 & $100 \%$ & 100 \\
\hline 25 & 4 & 12 & 4 & $100 \%$ & 3 & $75 \%$ & 75 \\
\hline 26 & 4 & 12 & 4 & $100 \%$ & - & - & - \\
\hline 27 & 4 & 12 & 2 & $50 \%$ & 2 & $50 \%$ & 25 \\
\hline 28 & 4 & 12 & 4 & $100 \%$ & 4 & $100 \%$ & 100 \\
\hline 29 & 4 & 13 & 3 & $75 \%$ & 2 & $50 \%$ & 37.5 \\
\hline 30 & 4 & 12 & 4 & $100 \%$ & 4 & $100 \%$ & 100 \\
\hline 31 & 4 & - & - & - & - & - & - \\
\hline 32 & 4 & 12 & 4 & $100 \%$ & 4 & $100 \%$ & 100 \\
\hline 33 & 4 & 13 & 4 & $100 \%$ & 4 & $100 \%$ & 100 \\
\hline Mean \pm Std & $3.39 \pm 0.9$ & $12.07 \pm 0.4$ & $3.30 \pm 0.9$ & $95.19 \pm 13$ & $3.18 \pm 1.0$ & $97.34 \pm 8.4$ & $89.20 \pm 24$ \\
\hline
\end{tabular}


Table 4. Oriental skylark nests dimensions recorded in Bajaur, from March to July 2018 and 2019 respectively

\begin{tabular}{|c|c|c|c|c|c|c|c|}
\hline $\begin{array}{l}\text { N. } \\
\text { No. }\end{array}$ & Look of nest & E. D. (cm) & I. D. (cm) & $\begin{array}{l}\text { C. D. } \\
\text { (cm) }\end{array}$ & $\begin{array}{c}\text { N. W. } \\
\text { (g) }\end{array}$ & Nest Materials & $\%$ \\
\hline 1 & Complete .R & 9 & 7 & 5.6 & 17 & Dichanthium annulatum & 18 \\
\hline 2 & Completely .R & 8.5 & 7.5 & 5.9 & 16.8 & Desmostachya bipinnata & 15 \\
\hline 3 & Completely .R & 8 & 7 & 6.2 & 16 & Heteropogon contortus & 15 \\
\hline 4 & Partial .R & 8.8 & 7.6 & 6 & 18 & Cynodo ndactylon & 18 \\
\hline 5 & Completely .R & 10 & 8 & 5.8 & 18 & Fimbristylis squarrosa & 10 \\
\hline 6 & Completely .R & 10.5 & 8.3 & 6 & 19 & Phragmites communis & 5 \\
\hline 7 & Completely .R & 9.5 & 8 & 5.5 & 17 & Local crops dry leaves & 14 \\
\hline 8 & Oblong . $\mathrm{R}$ & 9.6 & 7.9 & 6 & 17.5 & Plastic string & 2 \\
\hline 9 & Partial .R & 8.4 & 8 & 6 & 18.2 & unknown & 1 \\
\hline 10 & Completely .R & 8.5 & 8 & 5.7 & 19 & & \\
\hline 11 & Completely .R & 8.3 & 8 & 5.5 & 16 & & \\
\hline 12 & Completely .R & 10.5 & 9 & 6.6 & 17.9 & & \\
\hline 13 & Completely .R & 10.2 & 9 & 6.9 & 19 & & \\
\hline 14 & Completely .R & 10 & 8.8 & 5.8 & 17 & & \\
\hline 15 & Partial .R & 10 & 8 & 7 & 16.8 & & \\
\hline 16 & Oblong. $\mathrm{R}$ & 9 & 7.2 & 6 & 17 & & \\
\hline 17 & Complete .R & 9 & 7 & 5.7 & 18 & & \\
\hline 18 & Completely .R & 9.5 & 7.2 & 6.2 & 17 & & \\
\hline 19 & Completely .R & 9.5 & 7.5 & 6.8 & 19 & & \\
\hline 20 & Partial .R & 10.5 & 8 & 5.8 & 17.5 & & \\
\hline 21 & Completely .R & 8.9 & 7 & 6 & 17.2 & & \\
\hline 22 & Completely .R & 10.5 & 8 & 7 & 17 & & \\
\hline 23 & Completely .R & 10 & 8 & 5.6 & 18.6 & & \\
\hline 24 & Oblong .R & 9.5 & 8 & 7.4 & 18.4 & & \\
\hline 25 & Complete .R & 8.8 & 7.5 & 6 & 16 & & \\
\hline 26 & Completely .R & 8.2 & 7.8 & 7 & 17 & & \\
\hline 27 & Partial .R & 10.7 & 8.2 & 5.8 & 18.9 & & \\
\hline 28 & Complete .R & 11 & 9 & 6.5 & 19.2 & & \\
\hline 29 & Completely .R & 10 & 9 & 7 & 17 & & \\
\hline 30 & Completely .R & 9 & 7 & 6 & 18 & & \\
\hline 31 & Completely .R & 8.9 & 7.2 & 6 & 19 & & \\
\hline 32 & Completely .R & 9.8 & 7.9 & 7.2 & 16.8 & & \\
\hline 33 & Completely .R & 10.5 & 8 & 6.7 & 16.4 & & \\
\hline \multicolumn{2}{|c|}{ Mean \pm Std } & $9.48+0.8$ & $7.86+0.6$ & $\begin{array}{c}6.21+0 \\
.5\end{array}$ & $\begin{array}{c}17.61+ \\
0.9\end{array}$ & & 100 \\
\hline
\end{tabular}

\section{Discussion}

Oriental skylark breeding biology and nidology were studied in district Bajaur. All the nests were found on dry land. Campbell et al. [9] also reported the Oriental skylark nests from dry habitats in grasslands. In Tibetan Plateau, the Oriental skylark selects dry habitat for nest constriction on land which has bulky grasses that are helpful in delaying avian as well as land predators [12]. We continued to investigate the breeding period from April to July both in 2018 and 2019. Delius [21] reported Oriental skylark 
nesting in Britain on farmlands in early June and egg laying in early July

We observed the anthropogenic and predation impact on the nests as two nests (containing two and four eggs) out of 10 were demolished before hatching thus the hatching success is $79.41 \%$. Wilson and Browne et al. [22], Mouton et al. [23], and Poulsen et al. [24] also reported the destruction of Oriental skylark and other songs birds nests by predation and agricultural activities.

The clutch size ranged from two to four eggs [25] similarly in northern latitudes clutches of two to four were recorded. Normally in the mid breeding season, the clutch size ranged from three to five [26, 27]. The 12 days incubation period was recorded (ranged 11 to 13; on an average 12.07 days). Similarly, in the early study, it was also shown that the Oriental skylark incubation period takes 1213 days [28]. During 2011-12 a similar research was conducted in Tibetan Plateau where about 12.04 days incubation period was recorded the nesting success of oriental skylark was measured as $41.3 \%$ in Tibetan Plateau [12].

The egg profile was smooth, sometimes rough, mainly oval varying to roundish and color dusty to grey white with small black spots. Though, in an earlier investigation, it was noted that Oriental skylark eggs were grey white to greenish with a brunette spot. Another view was that the eggs were of a grey-white or greenish background covered in brown or olive spots $[3,29]$.

The average mass of 112 eggs was about $3.0 \pm 0.12 \mathrm{~g}$. The average length, width, and volume were $1.8,2.23 \pm 0.4 \mathrm{~cm}$ and $3.65 \pm 0.07$ $\mathrm{cm}^{3}$ respectively. Cramp and Brook [3], Praus and Weidinger [5] reported the Oriental skylark egg length, width and mass as about 1.7 to $8 \mathrm{~cm}, 2.3$ to $2.4 \mathrm{~cm}$ and $3.3 \mathrm{~g}$ respectively.

Oriental skylark overall nest success in the study area was $89.20 \%$. In Northern Netherlands and in Europe a slightly less nest success in natural and arable fields was $33 \%$ [30]. In the present study nest achievement was not explored fully, suggesting that the nesting habitat is unsafe Kuiper et al [31], During the whole survey, female Oriental skylark was observed laying on eggs, similarly, Stoleson and Beissinger [32], Donald [33], Donald [34] recorded that unsafe nesting habitat decreased the population density of Oriental skylark. Marti [35] and Jose and Soler [36] reported the nesting and parental behavior of birds. Only the female incubates the eggs typically starting with the laying of the last egg [37].

We suggest that Oriental skylark is adapted to natural vegetated areas and arable fields, and selects a nest site to minimize human and livestock interruption. Skylark breeding success can be improved by protecting its habitat and by raising awareness amongst the local peoples. The study would support the conservation of Oriental skylark throughout its area of distribution.

\section{Authors' contributions}

Conceived and designed the experiments: $\mathrm{K}$ Gabol, Performed the experiments: RU Khan, Analyzed the data: RU Khan \& K Gabol, Contributed materials/ analysis/ tools: K Gabol, Wrote the paper: RU Khan.

\section{Acknowledgements}

The authors acknowledge the University of Karachi and locals of the study areas.

\section{References}

1. Duckworth JW, Davidson P, Evans TD, Round PD \& Timmins RJ (2002). Bird records from Laos, principally the upper Lao/Thai Mekong and Xiangkhouang Province, in 1998-2000. Forktail 11-44.

2. Donsker FGD (2014). IOC World Bird List.

3. Cramp $\mathrm{S} \&$ Brooks DJ (1992). Handbook of the birds of Europe, the Middle East and North Africa. The birds of the western Palearctic, Oxf Uni Press, Oxford Vol. VI. Warblers (pp. 396-405). 
4. Zheng GM, Zhang ZW, Ding P, Ding CQ, Lu X \& Zhang YY (2002). A Checklist on the Classification and Distribution of the Birds of the World.

5. Praus L \& Weidinger K (2010). Predators and nest success of Sky Larks Alauda arvensis in large arable fields in the Czech Republic. Bird Study 57(4): 525-530.

6. Toochin R \& Meredith M (2018). Status and occurrence of Eurasian Skylark (Alauda arvensis) in British Columbia. Ibis.

7. Gill F \& Donsker D (2013). IOC world bird list (Version 3.3). Inter Ornith' Union (doi: 10. 14344/IOC. ML. 3.5).

8. Little RM (2016). Roberts Bird Guide. Ostrich 1(2).

9. Campbell RW, Dawe NK, McTaggartCowan I, Cooper JM, Kaiser GK \& McNall MCE Smith GEJ (1997). The Birds of British Columbia. Vol. 3, Passerines: flycatchers Through Vireos University

10. Du B, Liu CJ, Yang M, Bao SJ, Guan MM \& Liu NF (2014). Horned larks on the Tibetan Plateau adjust the breeding strategy according to the seasonal changes in the risk of nest predation and food availability. $J$ of Avi Biol 45(5): 466-474.

11. Fitzpatrick S (1997). Patterns of morphometric variation in birds' tails: length, shape and variability. Biol $J$ of the Linnean Soc 62(1): 145-162.

12. Li S, Peng W \& Guo C (2015). Factors affecting nest success of the Oriental Skylark on the Tibetan Plateau. Ornithol Sci 14(1): 47-52.

13. Gregory RD, Van Strien A, Vorise P, Gmelig AW, Noble D, Foppen RP \& Gibbons DW (2005). Developing indicators for European birds. Philosophical Transactions of the Royal Society B: Biol Sci 360(1454): 269-288.
14. Gregory RD, Van SA, Vorisek P, Gmelig MAW, Noble DG, Foppen RP \& Gibbons DW (2005). Developing indicators for European birds. Philosophical Transactions of the Royal Society B: Biol Sci 360(1454): 269-288.

15. Shurulinkov $P$ (2005). On the Breeding Biology of Skylark, Alauda arvensis cantarella (Aves: Passeriformes) in West Bulgaria. Acta Zool Bulgarica, 57: 207216.

16. Nilsen EB, Moa PF, Broseth H, Pedersen HC \& Hagen BR (2020). Survival and migration of rock ptarmigan in central Scandinavia.

17. Khan RU, Sadam A \& Mahmood S (2021). Population Ecology of Chakor Partridge (Alectoris chukar) in District Bajaur, Khyber Pakhtunkhwa, Pakistan. Pak J Zool 52.

18. Khan RU \& Gabol K (2021). Breeding Biology of Chakoor Partridge (Alectoris chukar) in Bajaur, KhyberPakhtunkhwa, Pakistan: Critically Affected by Eggs Collection and Predation. Pure and Appl Biol 10(3): 913-921.

19. Wahid S, Khurshaid K \& Nazma HK (2020). Sand Fly (Diptera: Psychodidae) Species Diversity, Habitat Preferences, and Ecological Aspects of Distribution in Bajaur District, Khyber Pakhtunkhwa, Pakistan. J of Med Ento XX(X), 2020, 18 doi: 10.1093

20. Kour DN \& Sahi DN (2013). Aspects of breeding biology of cattle egret, Bubulcus ibis coromandus (Boddaert) in Jammu, India. Int J Environ Sci 3(5): 1547-1561.

21. Delius JD (1965). A population study of Western Oriental skylark (Alauda gulgula inconspicua) vensis. Ibis 107(4): 466-492.

22. Wilson JD \& Browne SJ (1993). Habitat selection and breeding success of 
Skylarks Alauda arvensis on organic and conventional farmland. BTO Res Rep (129): 1-47.

23. Mouton JC, Tobalske BW, Wright NA \& Martin TE (2019). Compensatory Plasticity offsets Performance and Survival Costs of Predation Risk across Life Stages. Developmental, Ecological, and Life History Influences on Predator induced Plasticity in Songbirds, 1001: 9.

24. Poulsen JG, Sotherton NW \& Aebischer NJ (1998). Comparative nesting and feeding ecology of Skylarks Alauda arvensis on arable farmland in southern England with special reference to setaside. J of Appl Ecol 35(1): 131-147.

25. Ribic CA, Thompson $\mathrm{W} \&$ Ynia AL (2013). Effects of nest-site selection, brood parasitism, and predation on the nesting success of passerines breeding in bottomland hardwood forests in eastcentral Arkansas. Arkansas State University.

26. Tucker G \& Moseikin VN (1994). Birds in Europe. Their conservation status.

27. Browne S, Vickery J \& Chamberlain D (2000). Density and population estimate of breeding Skylarks in Britain in 1997. Bird Study 47(1): 52-65.

28. Barraclough TG, Harvey PH \& Nee S (1995). Sexual selection and taxonomic diversity in passerine birds. Proceedings of the Royal Society of London. Series B: Biol Sci 259(1355): 211-215.

29. Hoyt DF (1979). Practical methods of estimating volume and fresh weight of bird eggs. The Auk 96(1): 73-77.
30. Kragten S, Trimbos KB \& Desnoo GR (2008). Breeding Skylarks (Alauda arvensis) on organic and conventional arable farms in the Netherlands. J of Agri Ecosys \& Environ 126(3-4): 163-167.

31. Kuiper MW, Ottens HJ, Van RJ, Koks BJ, Dsnoo GR \& Berendse F (2015). Effects of breeding habitat and field margins on the reproductive performance of Skylarks (Alauda arvensis) on intensive farmland. $J$ of Ornith 156(3): 557-568.

32. Stoleson SH \& Beissinge SR (1995). Hatching asynchrony and the onset of incubation in birds, revisited. In Current ornithology (pp. 191-270). Sprin, Boston, $M A$

33. Donald PF \& Morris TJ (2005). Saving the skylark. British Birds 98: 570-578.

34. Donald PF, Evans AD, Muirhead LB, Buckingham DL, Kirby WB \& Schmitt SEII (2002). Survival rates, causes of failure and productivity of Western Oriental skylark (Alauda gulgula inconspicua) nests on lowland farmland. Ibis 144(4): 652-664.

35. Marti TE (1993). Nest predation among vegetation layers and habitat types: revising the dogmas. The Am Nat 141(6): 897-913.

36. Jose J, Moller AP \& Soler M (1998). Nest building, sexual selection and parental investment. $J$ Evolutionary Ecol 12(4): 427-441.

37. Toochin R \& Meredith M (2018). Status and Occurrence of Eurasian Skylark (Alauda arvensis) in British Columbia. Ibis. 